\title{
Autopsy Findings on Decomposing Drowned Body: Identification of Specific Diagnostic Features of External, Internal, and Laboratory Examinations
}

\author{
Satria Perwira*(i), Tia Maya Affrita (D), Edwin Tambunan (D), Ahmad Yudianto (D) \\ Department of Forensic and Medicolegal Medicine, Faculty of Medicine, Universitas Airlangga, Surabaya, Indonesia
}

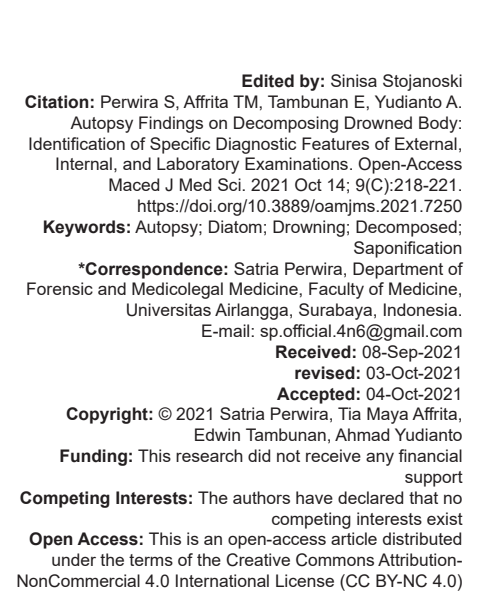

Abstract

BACKGROUND: Drowning is one type of asphyxia caused by the entry of fluid into the airway. Death due to drowning is one of the hardest things that are difficult to diagnose in the field of forensic medicine, primarily if the victim found to be in a decomposed state. The state of decomposed examination often does not show typical signs. The diagnosis of drowning can be reached after considering all the results of the forensic examination including external, internal, and laboratory examinations.

CASE PRESENTATION: A body has been found in the residential area on the east side of the beach, Tambaksarioso Village, Asemrowo District, on Tuesday, May 18, 2021, at 13.30 West Indonesian Time and reported to the police for investigation. The body was then identified at Dr. Soetomo General Hospital by a forensic expert. External, internal, and laboratory investigations were conducted. On external examination, the corpse was not intact, with signs of decay, saponification, and violation. In an internal examination, sand in the airways and other signs of drowning were identified. In the acid destruction test using the right femur, a positive diatom result was obtained.

CONCLUSION: A complete autopsy is vital to determine the cause and mechanism of death, reconstruct the events before death, and identify the victim. It is also essential to determine whether the deceased died by drowning was alive before entering the water. All injuries suffered by the victims should be described.

\section{Introduction}

The diagnosis of drowning is described in the literature as one of the more challenging in forensic pathology [1]. External examination and autopsy results are, in most cases, not specific, and laboratory investigations are controversial in the scientific community. Mainly if the drowned victim is decomposing, there are no typical signs. The diagnosis of drowning may be achieved after reviewing all the results of the forensic examination, including external examination, internal examination, and laboratory examinations [2]. According to the World Health Organization (WHO), in 2002, drowning refers to large quantity of fluid entering the respiratory tract or lungs. In the case of drowning, submersion of the whole body in the water is not necessary. Drowning is not only limited to deep waters such as seas, rivers, lakes, or swimming pools but may also be immersed in puddles or ditches where only the face is the underwater level which fluid covers the nostrils and mouth [2], [3], [4].

The WHO reports that $0.7 \%$ of global deaths or more than 500,000 deaths each year are caused by drowning. The $\mathrm{WHO}$ also noted that in $2004,388,000$ people worldwide died of drowning and ranked third in the world due to accidental injuries. According to the Global Burden of Disease, this number is lower than all drowning deaths due to floods, water transport accidents, and other disasters [4]. The highest incidence occurs in developing countries, particularly among children under 5 years old. In addition to age, other risk components that increase the incidence of drowning include gender, especially men who have a mortality rate double that of women, alcohol use, or drug abuse in $50 \%$ of cases involving adolescents and adults, unsupervised children [4]. The rest were caused by previous medical conditions (convulsions, nerve disease, and fainting) and attempted suicide. More drowning cases occur in freshwater (lakes, rivers, and ponds) by $90 \%$, and the remaining $10 \%$ occur in water sea [4].

\section{Case Illustration}

An incomplete and decomposed body with no identity has been found in drowned position by the 
residents on the east side of the beach of Surabaya, on Tuesday, May 18, 2021, at 13.30 West Indonesia Time and reported to the police for investigation (Figure 1). The body was then identified at Dr. Soetomo General Hospital by a forensic expert. The body was received in a state of decomposition. We carry out an external, internal, and examination of diatoms. On the external examination, signs of advanced decay and saponification were found in the form of soft-tissue destruction on the face, loss of eyeballs, Blackish skin, destruction of genital organs, maggots' infestations with the most significant measurement $1.5 \mathrm{~cm}$; washer's woman's hand, pink teeth, blood infiltration in orbital cavity, right and left head, right upper arm, left lower leg, and fracture of right forearm, left palm, right lower leg, and left lower leg (postmortem) (Figure 2a-c).

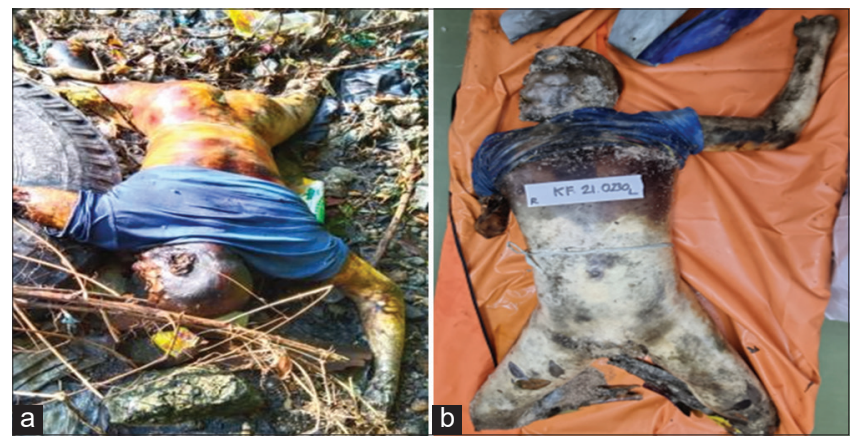

Figure 1: Drowning victim and the progression of decomposition (a) and incomplete and decomposed body (b)

On the internal examination, the organs were further decomposing. Sands were found in the throat, main airways, and bronchial branches; in the aorta, aortic hemolytic staining was found; in the lungs, edema aquosum and Paltauf's spots were found; in the middle ear and temporal bone, Neil's sign was found (Figure $2 \mathrm{~d}-\mathrm{g}$ ). Blood infiltration was also found on the right and left sides of the skull. In laboratory, a destruction test using the left femur was conducted. On examination under a microscope, we found the presence of translucent diatoms.

\section{Discussion}

Decomposition is formed by two processes: Autolysis (destruction of cells and organs by intracellular enzymes) and putrefaction (caused by bacteria and fermentation). Decomposition will appear approximately $24 \mathrm{~h}$ after death, in the form of a greenish color in the lower right abdomen, gradually becoming visible and spread throughout the stomach, chest, and cause a foul smell. According to Casper's law, the environment in which the body is located also plays a role in the process of decay. The proportion rate of corpses decay in air, water, and soil is 1:2:8 [2], [3]. From the examination of the drowned body, there were maggots on the bodies and in a state of the stage of decay (Figure 1). We concluded the time of death between 4 and 14 days before the examination of the body.

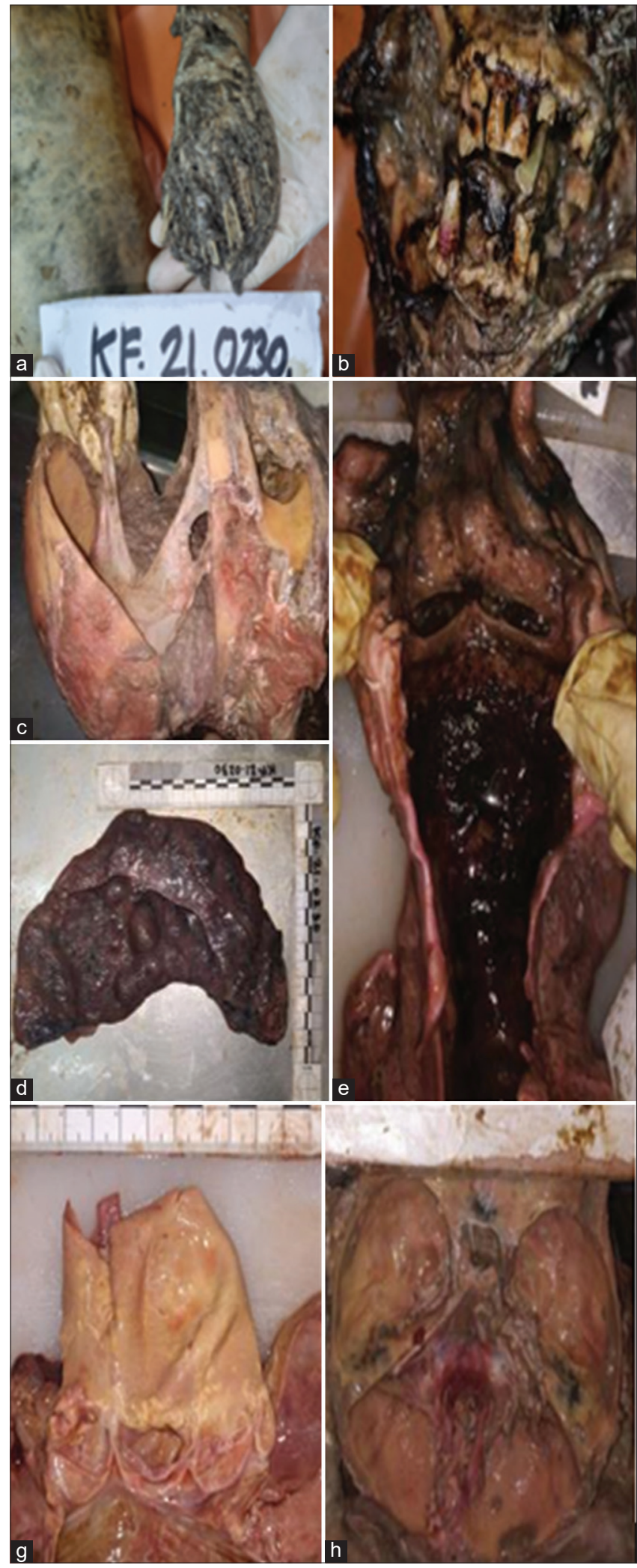

Figure 2: Findings of external and internal investigations of victim. (a) Washer woman's hand. (b) Pink teeth. (c) Blood infiltration on the right and left skull bones (blood infiltration also seen on the right upper arm, right shin bone, and right orbital bone). (d) Sand in the trachea, bronchus, and bronchioles. (e) Enema aquosum and Paltauf's spot. (f) Aortic staining hemolytic. (g) Neil's sign 
The diagnosis of death by drowning is sometimes challenging to establish if there are no distinguishing features on the external and internal examination [2]. In our case, from external examination, the skin along the back of the palms was pale, wrinkled, and wet, which indicated the presence of a washer woman's hand caused by fluid inhibition into the cutis (Figure 2a). In addition, victims who died from drowning often show cadaveric spasm, which is an intravital sign that occurs when the victim tries to save himself by holding anything such as grass or other objects in the water, or abrasions on the elbows, fingers, knees, and feet due to friction of objects in the water [2], [3], but in this corpse, it was difficult to determine because of the decomposition and the loss of extremities.

Pink teeth were found in incisive 1 , incisive 2 , canine, premolar one on the right upper jaw, and canine right lower jaw (Figure $2 b$ ). The color was more prominent in the canine right lower jaw. In forensic pathology context, pink teeth have often been observed in drowning victims but have also been reported in subjects who died suddenly and are not associated with drowning. There is a general agreement that there is no apparent connection between the present of pink teeth and the cause of death. However, the condition of the surroundings (in particular humidity) must undoubtedly play an essential role in developing the pink tooth phenomenon, indicating that the diffusion of the blood in the pulp into the dentinal tubules causes the red discoloration of the teeth. Based on the results, the pigmentation is more prominent on the teeth with single roots than in the posterior teeth with multiple roots [5].

Facing the case of a drowning body, one must think about why and how the person drowned to understand the mechanism of death; whether the death was natural, accidental, suicide, and/or homicide [3]. In this case, visually visible blood infiltration was found in the right upper arm, right shin bone, right orbital bone, and right and left skull bones, did not disappear when cleaned with no visible fractures (Figure 2c). Blunt trauma of the bone will cause blood to come out of the veins and arteries damaged by the trauma to the tissue around the trauma site (hematoma). Therefore, if the force applied is not enough to cause a fracture, the presence signs of violence can still be found. In addition to causing a hematoma in the soft tissue above the bone, the blunt force can also cause a hematoma on the bone itself (bone bruising). There are three types of bone brushing: (a) Subperiosteal hematoma (subperiosteal hemorrhage, where there is an accumulation of blood between the periosteum and the bone cortex); (b) interosseous hematoma (arising from repeated trauma to the bone); and (c) subchondral lesion. The presence of a subperiosteal hemorrhage is a sign of intravital [6].

From the internal examination, we found sand in the trachea, bronchus, and bronchioles (Figure 2d).
Sand, mud, and aquatic plants are often found in the respiratory tract and even the digestive tract. This can be caused by the victim inhaling and swallowing these objects while in the water [7].

Examination of the lungs revealed that there were round, black patches on the lower surface of the lower lobes of the lungs. These spots are referred to as Paltauf's spots (Figure 2e). The spots of bleeding that occurs due to increased pressure, leading to rupture of the alveolar walls, mostly found on the anterior surface and border of the lung, but can also be found in the subpleural if there has been further leakage or rupture [8]. We also found bubbles in the lungs, which, when the incision was made, a black liquid came out. These fluid-filled bubbles are called edema aquosum resulting from the redistribution of osmotic fluid into the alveolar space with hypertonic hyperhydration occurring during saltwater submersion. After weighing, lung weight did not increase from the average lung weight of about 250-300 g [10].

During the heart examination, in the aorta, aortic hemolytic stains were identified (Figure 2f). In forensic literature, new methods are reported to improve the diagnosis of drowning death. This includes aortic hemolytic coloration, the reddish imbibition of the aortic vascular wall, formed by the release of hemoglobin from hemolysis. However, this method is not specific to drowning alone, as similar observations may be made in cases of decay, sepsis, or burning injuries [9].

On examination base of the skull, a black field was found in the form of bleeding into the middle ear cavity and blood adhering to the mastoid process, which was probably caused by pressure changes during the drowning process. This was referred to as Neil's sign (Figure $2 \mathrm{~g}$ ). This is accomplished by opening the head and looking at the middle ear and spongy stratum of the mastoid bone. Bleeding points can be found on the mucous membranes of the mastoid bone and middle ear, which is a strong indication of drowning [10].

Additional tests that can be done to strengthen the diagnosis of death due to drowning are diatom examinations. This diatom examination was carried out on the bone marrow of the femur because the body had decomposed. Diatoms are microscopic unicellular algae that vary in size from 5 to more than $500 \mathrm{~m}$ (Figure 3). If a person dies from drowning, the liquid with diatoms will enter the respiratory or digestive tract and into the bloodstream through the capillary walls that were damaged when the victim was alive [11].

In terms of identification, fingerprinting cannot be taken because the body has been decomposed. For this, we carried out a dental examination and took the clavicle for a DNA test. In addition, we also used the pattern of the palate, nasal bones, and cheekbones 
for racial identification; head and pelvis for sex; teeth, sutures in the skull, and visualization of the ossification center for age identification; and the femur bone for height identification using the trotter glacier formula. On examination, the body was male, aged between 40 and 60 years, height between 154 and $169 \mathrm{~cm}$, and Mongoloid race [12].

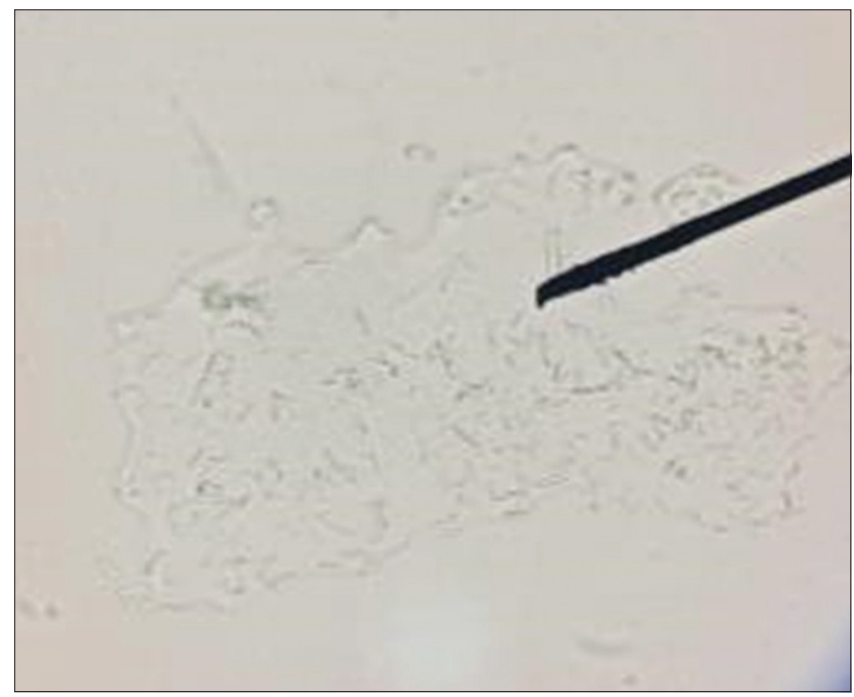

Figure 3: Translucent diatom in microscopic investigation

\section{Conclusion}

We reported one case of drowning with the incomplete and decomposed body; the estimated time of death was 4-14 days before the external examination of the body was carried out. The case was a male, aged between 40 and 60 years, body length between $154 \mathrm{~cm}$ and $169 \mathrm{~cm}$ and had Mongoloid race. From the external examination and internal examination, it is strongly indicated that the death was caused by drowning, where there were also signs of violence. This was also confirmed by analysis of the diatoms, which showed the presence of translucent diatoms during the examination of femur bone marrow. In this case, the drowning incident was concluded as unnatural death, caused by the entry of water into the respiratory tract and closing the airway, causing suffocation, resulting in asphyxiation.

\section{Acknowledgment}

We would like to thank staff of the Department of Forensic and Medicolegal Medicine, Faculty of Medicine, Universitas Airlangga, Surabaya, Indonesia.

\section{References}

1. Piette $M H$, De Letter EA. Drowning: Still a difficult autopsy diagnosis. Forensic Sci Int. 2006;163(1-2):1-9. https://doi. org/10.1016/j.forsciint.2004.10.027

PMid:16378701

2. Budiyanto A, Widiatmaka $W$, Sudiono $S$, Winardi T, Mun'in A, Sidhi S, et al. Forensic Medicine. $1^{\text {st }}$ ed. Jakarta: Forensic Medicine Division, Faculty of Medicine, University of Indonesia; 1997.

3. Sauko P, Knight B. Knight's Forensic Pathology. $4^{\text {th }}$ ed. United States: CRC Press; 2015.

4. Campobasso CP, Vella GD, Donno AD, Santoro V, Favia G, Introna $F$. Pink teeth in a series of bodies recovered from a single shipwreck. Am J Forensic Med Pathol. 2006;27(4):313-6. https://doi.org/10.1097/01.paf.0000233544.58567.81 PMid:17133027

5. World Health Organization. Drowning. Key Facts. Geneva: World Health Organization; 2021.

6. Mira Wiryaningsih MA. Validitas Resapan Darah Pada Tulang Sebagai Petunjuk. Indonesian: Pertemuan IImiah Tahunan; 2017. p. 15-6.

7. Yudianto A. IImu Kedokteran Forensik, IImu Kedokteran Forensik (Interaksi Dan Dependensi Hukum Pada IImu Kedokteran). East Java, Indonesian: Scopindo Media Pustaka; 2020. https://doi. org/10.18196/mls.v1i2.8345

8. Putra AA. Death by drowning: A case report. J Medika Udayana 2014;3(5):542-551

9. Byard RW. Aortic intimal staining in drowning. Forensic Sci Med Pathol. 2015;11:442-4. https://doi.org/10.1007/s12024-014-9563-6 PMid:24752425

10. Schneppe S, Dokter M, Bockholdt B. Macromorphological findings in cases of death in water: A critical view on drowning signs. Int J Legal Med. 2021;135(1):281-91. https://doi. org/10.1007/s00414-020-02469-9 PMid:33586029

11. Pollanen MS. Diatoms and homicide. Forensic Sci Int. 1998; 91(1):29-34. https://doi.org/10.1016/s0379-0738(97)00162-x PMid:9493342

12. Hidayat T, Susanti R. Analisis Antropologi Forensik Pada Kasus Penemuan Rangka Di Dalam Koper. Indonesian: Pertemuan IImiah Tahunan; 2017. p. 281-5. 